\title{
Calcium Deficiency Symptoms of Epipremnum aureum
}

\section{Catherine S.M. Ku ${ }^{1}$ and David R. Hershey ${ }^{2}$ \\ Department of Horticulture, University of Maryland, College Park, MD 20742-5611}

Additional index words. foliage plant, plant nutrition, pothos, solution culture, tissue analysis

Dickey and Joiner (1966) reported Ca deficiency symptoms occurring first on old leaves of heartleaf philodendron (Philodendron scandens ssp. oxycardium C. Koch \& H. Sell.) and pothos [Epipremnum aureum (Linden \& Andre) Bunt.], with youngest leaves the last to develop symptoms. However, heartleaf philodendron grown in $\mathrm{Ca}$ deficient nutrient solution developed symptoms on young shoots and leaves while old leaves were not affected (Hershey and Merritt, 1987). The Ca-deficient plants recovered when $\mathrm{Ca}$ was added to the nutrient solution. The study reported here examined $\mathrm{Ca}$ deficiency of pothos to determine if symptoms develop first on young leaves, as is typical for higher plants, or on old leaves, as observed by Dickey and Joiner (1966).

Fifty terminal shoot cuttings, each with one fully expanded leaf, were rooted under intermittent mist in tap water in a hydroponic propagation system (Hershey, 1989). When well rooted, the plants were transferred to a static solution (0.9 liters/jar) culture system (Hershey and Merritt, 1986), but with polyethylene reservoirs and with a modified aeration manifold (Sadof and Hershey, 1989). Deionized water and reagent-grade chemicals were used for nutrient solutions. Half the plants were grown in Hoagland \#1 solution with $90 \mu \mathrm{M}$ NaFeEDTA instead of Fe tartrate (Hoagland and Arnon, 1950). The remaining plants were grown in the same solution, except $\mathrm{Ca}\left(\mathrm{NO}_{3}\right)_{2}$ was omitted. Plants were grown in a glasshouse with air at a minimum of $20 \mathrm{C}$ and with natural ventilation.

After 4 months in the same solution, when the - Ca plants had severe symptoms, 10 were placed in fresh $+\mathrm{Ca}$ solution and 10 in a fresh - Ca solution. These plants were grown for another 5 months without solution

Received for publication 13 Aug. 1990. Scientific article no. A6067, Contribution no. 8229, of the Maryland Agricultural Experiment Station. The cost of publishing this paper was defrayed in part by the payment of page charges. Under postal regulations, this paper therefore must be hereby marked advertisement solely to indicate this fact. 'Graduate Assistant.

${ }^{2}$ Assistant Professor, to whom reprint requests should be addressed. renewal because the plants grew slowly in fall/winter. No nutrient deficiency symptoms appeared on the $+\mathrm{Ca}$ plants.

Also after 4 months, upper, middle, and lower leaf samples were collected from five of the $+\mathrm{Ca}$ plants. Upper leaves with $\mathrm{Ca}$ deficiency symptoms and lower leaves with no symptoms were collected from five of the - Ca plants. Leaf samples were oven-dried at $65 \mathrm{C}$, ground, ashed in a muffle furnace for $3 \mathrm{~h}$ at $550 \mathrm{C}$, and analyzed for $\mathrm{Ca}$ with a Perkin-Elmer (Norwalk, Corm.) atomic absorption spectrophotometer model 2380.

The - Ca plants developed symptoms similar to those reported for heartleaf philodendron (Hershey and Merritt, 1987) and other higher plants (Epstein, 1972). The earliest symptom was necrosis of root tips followed 2 to 6 weeks later by chlorotic spots located randomly on the uppermost leaf and by leaf distortion of expanding leaves. Soon after these symptoms appeared, the shoot tip became necrotic and the uppermost leaf became completely chlorotic. These symptoms were followed by necrotic spotting, marginal necrosis, and total necrosis of the uppermost leaf. This pattern of symptom development then progressed down the stem. Basal leaves remained symptomless.

Leaf $\mathrm{Ca}$ concentration in deficient (upper) leaves was only $11 \%$ or less of the concentration in normal leaves (Table 1). In $+\mathrm{Ca}$ plants, $\mathrm{Ca}$ concentrations were highest in the lower and middle leaves. Lower, healthy leaves on severely deficient plants had $44 \%$ of the $\mathrm{Ca}$ concentration in leaves on $+\mathrm{Ca}$ plants. The very low $\mathrm{Ca}$ concentration in the upper, deficient leaves of the - Ca plants supports the hypothesis that the symptoms were caused by a Ca deficiency and indicates that no major translocation of $\mathrm{Ca}$ from lower to upper leaves occurred.

The Ca-deficient plants placed in fresh $+\mathrm{Ca}$ or - Ca solutions both unexpectedly had new, healthy-appearing root tips emerge within 2 days after the change in solution. However, the $-\mathrm{Ca}$ root tips did not grow as rapidly as those in the $+\mathrm{Ca}$ solution, and the new root tips in the $-\mathrm{Ca}$ solution soon became necrotic, while the root tips in the $+\mathrm{Ca}$ solution grew normally. This pattern of new root tips emerging, then dying, was repeated several times in the $-\mathrm{Ca}$ solution, most likely due to leaching of small amounts
Table 1. Calcium concentration in pothos leaf blade, with petiole, from plants grown with and without $\mathrm{Ca}$ in the nutrient solution. ${ }^{2}$

\begin{tabular}{lcr}
\hline \hline Treatment & Leaf position & $\mathrm{Ca}(\%)$ \\
\hline$+\mathrm{Ca}$ & Upper & $1.71 \pm 0.19$ \\
& Middle & $2.69 \pm 0.07$ \\
& Lower & $2.91 \pm 0.09$ \\
$-\mathrm{Ca}$ & Upper & $0.192 \pm 0.018$ \\
& Lower & $1.29 \pm 0.067$ \\
\hline
\end{tabular}

${ }^{2}$ Data represent means $\pm \mathrm{sE} ; \mathrm{n}=5$ for $-\mathrm{Ca}$, but $\mathrm{n}=4$ for + Ca because of the loss of one set of tissue samples before analysis.

of $\mathrm{Ca}$ into the nutrient solution from the mostly necrotic and rotted root system.

The $-\mathrm{Ca}$ plants placed in the $+\mathrm{Ca}$ solution recovered completely, developing a healthy new root system and several vigorous lateral shoots. The - Ca plants placed in new - Ca solution did not change significantly; thus, Ca deficiency was confirmed as the cause of the symptoms. Even after 9 months in - Ca solution, one or two basal leaves remained healthy on - Ca pothos, although the root system appeared totally necrotic.

Although the - Ca solution contained only one-third the $\mathrm{N}$ concentration as the $+\mathrm{Ca}$ solution, as recommended by Hoagland and Arnon (1950), no symptoms of N deficiency appeared on the - Ca plants.

Pothos, like heartleaf philodendron (Hershey and Merritt, 1987), does not develop Ca deficiency symptoms on old leaves, contrary to Dickey and Joiner (1966), and apparently does not translocate enough $\mathrm{Ca}$ from old to young leaves to prevent $\mathrm{Ca}$ deficiency symptoms on young leaves (Joiner et al., 1983). Rather, pothos has Ca deficiency symptoms like those of other higher plants, with chlorosis and necrosis of root tips, shoot tips, and young leaves (Epstein, 1972).

\section{Literature Cited}

Dickey, R.D. and J.N. Joiner. 1966. Identifying deficiencies in foliage plants. Southern Florist \& Nurseryman 79(20):38, 42-43.

Epstein, E. 1972. Mineral nutrition of plants: Principles and perspectives. Wiley, New York.

Hershey, D.R. 1989. Easily constructed, inexpensive hydroponic propagation system. HortScience 24:706.

Hershey, D.R. and R.H. Merritt. 1986. A simple, inexpensive, static solution culture system. HortScience 21:1062-1063.

Hershey, D.R. and R.H. Merritt. 1987. Calcium deficiency symptoms of heartleaf philodendron. HortScience 22:311.

Hoagland, D.R. and D.I. Amen. 1950. The waterculture method for growing plants without soil. California Agr. Expt. Sta. Circ. 347.

Joiner, J.N., R.T. Poole, and C.A. Conover. 1983. Nutrition and fertilization of ornamental greenhouse crops. Hort. Rev. 5:317-403.

Sadof, C.S. and D.R. Hershey. 1989. An inexpensive aeration manifold for static solution culture systems constructed of commonly available components. Plant Physiol. Suppl. 89(4):203. (Abstr.) 